\title{
The Constitutional Review of Dissolving or Discharging the Local Government Units in Albania
}

\author{
Erind Merkuri \\ Faculty of Law - University of Tirana \\ Email: erind.merkuri@fdut.edu.al
}

\section{Doi:10.5901/mjss.2014.v5n23p581}

\begin{abstract}
The European continent now recognizes three types of vertical state organization, the federal, regional and unitary system. The latest form of organization has been selected by the Republic of Albania under the Constitution of 1998 but paying attention that this unitary form of the state should be based on the principle of decentralization and the autonomy of local government. However, as the practice shows today, very often, local government units have the tendency which exceed certain powers defined for them in the constitution and law, and in some places there is clear separatist tendencies aimed at the secession by the state. Precisely, in order to avoid these kinds of situations and to maintain the unitary form of the state, the Constitution of the Republic of Albania provides a control mechanism that allows the Council of Ministers to dissolve/discharge the local authorities, as well as, the right of the latter to complain to the Constitutional Court and to challenge the validity of this act. The purpose of this article is to give an overview of the Albanian jurisprudence and doctrine that addresses this issue.
\end{abstract}

Keywords: local unit, the Council of Ministers, Constitutional Court, the procedure of dissolution/discharging, causes, the procedure.

\section{Introduction}

In the sixth part and specifically Articles 108 to 115 , the Constitution regulates the organization and functioning of the local government. Under these provisions the units of the local governments are municipalities, communes and district, of which the first two are the basic units, while the district appears as a unit of second level. Despite this forecast, other units of local government can be created by law.

According to Article 109 of the Constitution, the representative organs of the basic units of local government are elected by general direct elections and by secret ballot. Given this status, thus being elected bodies, the local governments enjoy a strong legitimacy, because they are considered representative of the people. As such, the constitution recognizes to these bodies a range of competencies which they exert based on the principle of decentralization and local autonomy (Constitution 1998).

Despite that, Article 1 of the Constitution defines the Republic of Albania as a unitary and indivisible state. This means that regardless the autonomy, the local government units, must exercise in accordance with the constitutional principles and the relevant legal regulations.

To prevent potential abuse, the constitutional legislator, has determined that local government units are controlled by the Council of Ministers, which appoints a prefect as its representative on the district (Constitution 1998) and also the constitutional legislator has empowered the council of Ministers to take extreme measure, discharging or dissolving the local units. This option of the Council of Ministers is determined in Article 115 of the Constitution, a provision which has the following content:

1. A directly elected organ of a local government unit may be dissolved or discharged by the Council of Ministers for serious violations of the Constitution or the laws.

2. The dissolved or discharged organ may complain, within 15 days, to the Constitutional Court, and in this case the decision of the Council of Ministers is suspended.

3. If the right to complain is not exercised within 15 days, or if the Constitutional Court upholds the decision of the Council of Ministers, the President of the Republic sets a date for elections in the respective local unit.

This power is a pure intervention of the Council of Ministers in local government, it should be noted that there is a problem concerning the principles and concepts of the organization of a state. A directly elected body, always, has more legitimacy than an elected body from other bodies which are either not directly elected by the people. In this regard, the local government directly elected has much more legitimacy than the Council of Ministers, which is constituted in a mixed 
way, by the President and Parliament.

From the above it results that although the Constitution recognizes the principle of decentralization, for the sake of the unity of the country and to ensure an equal position with the local central government, has agreed to "distort" the principle of the exercise of sovereignty, leaving us to think that not always the direct sovereignty is the more legitimate sovereignty (Zaganjori, Anastasi, Çani, 2011).

Although the Constitution has given this opportunity to the Council of Ministers, once again it (the Constitution), in respect of the principle of separation and balance of powers, and aiming that this power of the executive does not become an abusive tool, the Constitution has given to the local authorities the right to complain to the Constitutional Court. The right of appeal represents a guarantee to the authorities of local government, when exercising their duties (Constitutional Court, 2009). This forecast represents a special competence of the Constitutional Court, which controls serious law or Constitution violation, investigate and adjudicate the underlying issue, acting as courts of ordinary judicial system (Constitutional Court, 2009).

\section{Subject of the Constitutional Control}

As quoted above, Article 115 of the Constitution provides the possibility of the Council of Ministers to dissolve or discharge only the directly elected bodies.

Directly elected bodies referred to in Article 109 of the Constitution are: the Executive Body (chairman) and the representative body (council) of the basic units of local government (Municipality and Commune).

When it comes to discharge a local organ, we refer to Mayor of the municipality/commune, which is the executive body having a monocratic nature. In the case of municipal/commune councils, which are representative collegial nature, is applies only the distribution measures.

As understood by the above analysis, the district, as local government units of the second level, are excluded from the disciplinary proceedings that the Council of Ministers may exercise against them.

Another element that cannot be controlled by the Constitutional Court is the discretion of the Council of Ministers to discharge or dissolve the directly elected body. From the content of Article 115 of the Constitution we see that in this provision is used the term "may", (Constitution 1998) meaning that the Council of Ministers is not obliged to proceed in each case for discharging or dissolving these bodies, but is at its discretion to assess the usefulness of such a measure in each case. This interpretation of constitutional norms is also consolidated by the jurisprudence of the Constitutional Court which has held this position:

The task of this Court is to assess whether the cause, having served for discharging the elected local government body, constitute a serious violations of the Constitution or laws, and not to assess the opportunity of the measure. The right to assess whether or not to take the measure of discharging, when the conditions laid down in Article 115 of the Constitution are present, the constitution has given this right to the Council of Ministers when the latter states that it may discharge or dissolve the directly elected body of local government, for serious violations of the Constitution or laws (Constitutional Court 2013)

From the above passage clearly results, that is not subject to constitutional control whether the Council of Ministers should have intervened or not for discharging or dissolve a local body, because the word "may" written in the constitutional provisions; bring the matter outside the constitutional jurisdiction.

\section{Appeal Deadline}

Unlike other procedural deadlines provided by the Law on the Constitutional Court, in the case of this trial, the procedural deadline is provided by the Constitution and is 15 days. This period does not start the day the decision is taken by the Council of Ministers, but the day it is communicated to the local units, respectively the council of municipal/commune if is dissolved or to the mayor of municipality/commune in case of discharging (Constitutional Court, 2011).

The beginning of this term relates to the nature that the decision of the Council of Ministers has, which due to the concrete relationship and the subject directed, makes this act an administrative act with individual effects. Referring to the provisions of Code of Administrative Procedure, the decision to proceed with the implementation of the act is notified to the parties to whom the original act is directed, before its execution begins. The 15-days deadline aims the authority (subject) to whom the act is addressed may have the possibility to know the reason of discharging or dissolving and can have the necessary time to prepare his defence.

The foregoing, results that the applicant is in a "comfortable" position, as it is sufficient for them to prove the time when the decision of the Council of Ministers is registered at the local unit. However, even in cases where it proves to be 
notified by other means and appeals within 15 days of receiving notice, the Court considers this fact sufficient to consider the request within the constitutional deadline. In one case the moment of publication of the decision of Council of Ministers in the Official Journal was considered as the moment of notification, although this decision was not recorded at the local unit's protocol (Constitutional Court 2013).

In all cases belongs to the Council of Ministers to prove the contrary, therefore CM has the burden of proof to prove the date on which the local body has effectively taken notice. We must underline that the CoM's publication on the official website it is not considered as official notification.

\section{Suspension of Implementation of the Act}

In paragraph 2 of Article 115 of the Constitution, is provided that the filing appeals to the Constitutional Court by the discharged or dissolved body, against the decision of the Council of Ministers, the implementation of the latter is suspended automatically. So, in this case we are dealing with an immediate suspension which, unlike other cases of suspension provided by Law of CC, it is not subject to assessment by the Constitutional Court.

In the case of disciplinary proceedings against the local government, taking into consideration the fact that we are dealing with directly elected bodies from the people, the Constitution itself has provided immediate suspension of the implementation of the decision of the Council of Ministers, thereby avoiding the consequences that can come from a positive decision of the Constitutional Court regarding the appeal notice. In the absence of this provision of law, we could have been facing a problematic situation, because on one side will have municipal elections from which would emerge executive and other representatives bodies, and on the other hand the Constitutional Court after review of the case may invalidate the decision for discharging or dissolving of the body. From this analysis is obvious that if such a situation is certified, the exercise of sovereignty by the people is seriously put into question.

\section{Constitutional Judgment}

The judgment of the Constitutional Court of disputes relating to the discharging or dissolving the directly elected bodies has its own characteristics. The judgment of the court is similar with a conflict of employment, which as a rule is judged by the ordinary courts system. In this process the parties submit their claims about the content of the conflict as well as evidence on which they base these claims (Abdiu, 2001). Regarding the burden of proof, each party has its procedural obligations. The requesting party has the obligation to prove and argue the unconstitutional character of the decision, while the interested party has the obligation to determine the actions or omissions that constitute serious violations of the Constitution and laws (Constitutional Court, 2008).

Among the features of this trial can be highlighted that the Constitutional Court examines the dispute in view of the fact as well as in terms of the interpretation and implementation of procedural and substantive law (Constitutional Court, 2013). The Constitutional Court, stated otherwise, controls the procedure of discharging or dissolving the local authority and the merits of the grounds alleged by the Council of Ministers, if they constitute a serious violation of the Constitution or the law. The first is the formal control of the process and the second is the substantive control.

One of the most important and fundamental elements of this constitutional adjudication is the time. This judgment is valuable only if the final decision of the Constitutional Court, is given within the four years term of the local authority, which is discharged or dissolved. The Constitutional Court's decision makes no legal value if given after the four years term has ended, even if the local bodies in charge would have been the same people who were previously processed. This reasoning is based on the fact that the election or re-election of the persons in charge of various local bodies constitutes a new mandate given from the people and the new mandate therefore, does not carry with them the previously committed violations. adjudication:

Below we are going to treat both procedural and substantive aspects that characterize this type of constitutional

\subsection{The Respect of the administrative procedure for discharging or dissolving the directly elected bodies.}

The procedure followed by the Council of Ministers for discharging or dissolving the directly elected bodies is an administrative procedure. Therefore this procedure should respect the right to a fair legal process detailed in ACP. In connection with this determination the Constitutional Court has held this position:

The Court emphasized that the right of individuals to a fair trial/hearing provided for in Article 42 of the Constitution, is 
not limited to the judicial process, but it can also apply to the administrative disciplinary process. In this sense, is noted that every organ of public authority, in the exercise of its constitutional and legal function, is obliged to respect the democratic standards of which have found their reflection in the Constitution. Prior recognition of the person against whom the action to dismiss is taken, with the materials that charge him with responsibility, respect for the right to be heard and defended, as by giving preliminary explanations, as well as when examining the issue, are some of the key elements that guarantee the constitutional right of everyone to a fair trial as a fundamental right (Constitutional Court, 2013).

Referring to the constitutional, legal and jurisprudential regulation is imperative that the proceeding body, must notify (the start of the process) to the body against which the proceedings has start, to make available materials, hear and then take the appropriate decision. As a general rule, the procedure for the Council of Ministers shall start from the Ministry, which jurisdiction includes the relationship with the local government. With the entry into force of the Constitution this power belonged to the Minister of Local Government, but after 2005, it has passed the competency to the Minister of Interior. As a rule, the responsible Minister must notify the authority against to which the proceeding for initiating proceedings has begun; it must care for the communication materials and preliminary explanations and hearing. The report prepared by the responsible Minister is submitted to the Council of Ministers for decision. In respect of the right to be heard and defend the Council of Ministers should listen once again the body being dissolved or discharged. In this regard the Constitutional Court stated that:

The right to be heard as part of the right to defence is also guaranteed in the administrative process before any institutions, regardless of the instance and its importance. This is accomplished through individual participation in the process itself and by submitting his arguments or his own chosen lawyer (Constitutional Court, 2006).

The procedure described above is the ideal procedure to be followed by the Council of Ministers in cases of this administrative proceeding. However the ACP recognizes cases when it is possible to avoid these stages, which according to the Constitutional Court it does not affect the right to a fair hearing. Thus, in the jurisprudence of this Court, we find the following position:

In similar cases, the Court has estimated that if the applicant was present during the controls exercised by the controlling bodies, has filed its objections about the violations mentioned in them, and are only those violations on which is based on the proposal and the decision to discharge him, we do not have a violation of the right to be defended (Constitutional Court, 2006).

So, if the body being processed has participated in the administrative proceeding initiated by the responsible minister and has had the opportunity to present his objections, then it is not necessary to be heard before the Council of Ministers, if the procedure before this body is based only in violations that came over by the Minister. The important thing to note is that the report of the responsible minister must contain not only the violations found, but it must contain as well explanations or setbacks of the body so that the decision-making process in the Council of Ministers can be fair.

Except for the above case, the Constitutional Court has also allowed other deviations. So if at the local unit are exercised controls by other state bodies, which have found violations and then proposed the Council of Ministers, or were taken by the latter as base for discharging or dissolving the local bodies, it should not be considered as violation of the right to a fair hearing, if the local authority has been participating in these controls and has had the opportunity to present his objections. If the minister responsible for local government supports its report to the following acts and violations proposed by other institutions, his failure to notify the opening of administrative proceedings as well as the further nonparticipation of the authority to be proceed, it is not considered by the Constitutional Court as violation of the right to a fair hearing. Thus the Constitutional Court has not considered a violation when the minister responsible for local government, has supported his request and report to the Council of Minister at the report compiled by the High Inspectorate of Declaration and Audit of Assets (Constitutional Court, 2011), High State Control (Constitutional Court, 2013), or in a criminal trial (Constitutional Court, 2013), which ended with a final decision.

Notwithstanding the foregoing, in cases where the proposal for dismissal is based on the controls exercised by other bodies of state administration, their conclusions and / or proposal, in principle are not binding to the Council of Ministers. In this case it belongs to the responsible minister for local government to assess whether these violations are attributable to such local authority may be regarded as "a serious violation of the Constitution or laws", conclusion which is supported by constitutional jurisprudence (Constitutional Court, 2013).

Another claim that arises frequently in requests addressed to the Constitutional Court by local authorities relates to the reasoning of the decision of the Council of Ministers which has dismissed or dissolved the directly elected local body. 
In all cases the decision of the Council of Ministers is based on the report of the responsible minister for local government who has proposed the dissolution or the discharged of the local authority, therefore under paragraph 1 of Article 109 of APC, this report is considered as a component of the act and thus of its reasoning (Constitutional Court, 2006). The decision of the Council of Ministers is considered reasoned, even when the report of the minister himself is based on reports, acts of the control of other administrative bodies that have controlled the local unit (Constitutional Court, 2013).

\section{Causes for Discharging or Dissolving the Directly Elected Body}

Recalling the terms of Article 115 of the Constitution ensure that the Council of Ministers may discharge or dissolve the directly elected bodies for two reasons, namely "a serious violation of the constitution" and "serious violations of the laws".

These two cases have in common "serious" violation. Therefore, according to this conception sanctioned by the Constitution, not every violation may serve as cause for discharging or dissolving such a body, but only for serious violations. The restriction for serious violations is set on purpose, starting from the idea that these bodies have their autonomy and can not be subject to extreme disciplinary measures for any kind of violation (Abdiu, 2001). Likewise the doctrine and jurisprudence has recognized that it is not enough, only a serious violation to initiate proceedings against the local authority and is not necessarily required to be repeated violations (Abdiu, 2001). If, however, some minor infringements are done repeatedly and as a result of it there are serious consequences for the functioning of the local government and the provision of services to the community, the totality of these minor violations can be regarded as a serious offense within the meaning of Article 115 of the Constitution. Below we are going to analyze the causes of these individually.

\section{A Serious Violation of the Constitution}

In connection with the first case, the discharging or dissolving of the local bodies due to serious violation of the constitution, there has been no judicial practice and therefore there is not a definition of the elements of this offense, to this date. According to the doctrine, serious violations that are committed against the Constitution may be actions or attitudes that clash with the content of provisions included of the six part of the Constitution (Abdiu, 2001).

Despite the referral that doctrine does only to the sixth part of the Constitution, my opinion is that other cases of serious violations of the Constitution can be found in other provisions of the basic act.

From the entirety of these provisions, deem that a violation of the Constitution could be considered:

a) Violation of the principle of unity and indivisibility of the Republic. According to this principle enshrined in paragraph 2 of Article 1 of the Constitution, the form of organization of the Republic of Albania is a unitary form. For this reason any such intention, declaration or decision of these bodies, which brings the secession of a part of its territory, shall be considered as "a serious violation of the Constitution" and in my opinion, the most serious offense that can happen to the country's fundamental act.

b) Running of the mayors of municipalities/commune in the general election in the same constituency that includes the place where they perform their duties. The nomination prohibition stems from Article 69 of the Constitution, which prohibits a number of high officials to run for election without first resign from their duties, obligation which is extended to the mayors too (Constitution, 1998). This attitude has a really base on consolidate constitutional jurisprudence (Constitutional Court, 2000).

Turning to our case, we can conclude that based on the constitutional provisions and the constitutional jurisprudence results evident that such an act would bring indisputably "serious violation of the constitution".

c) Non appointment of representatives of the municipality/commune in the district. According to the constitutional provisions the municipalities and communes delegate members to the regional council(Constitution, 1998). Not delegating these members can result in lack of constitution or non functioning of the regional council, and hence these institution's inaction in this regard, gives rise to a constitutional body as the regional council not to act and thus remain non-existent. It is this attitude that can pose serious violation of the Constitution.

d) Non exercising the delegated powers or non implementing the obligations imposed in accordance with the Constitution(Constitution, 1998). In this case if by law, to the local governments are delegated authority and/or have been given these obligations associated with respective costs and they neglect or refuse to perform their functions, then we would have serious breach of this constitutional provision. However, as the delegated powers and duties are imposed by law, their failure can be regarded as a "serious violation of the law", so we 
can have competitiveness of these two responsibilities of the local institutions.

e) Failure or omission to exercise the constitutional powers of local units. According to Article 113 of the Constitution, the local authorities enjoy a wide range of competencies, failure to implement them in favour of community brings grave violation of the Constitution and as a consequence disciplinary responsibility of the relevant authorities. Nevertheless, in this case, these powers are detailed and elaborated in further various laws enacted by the Parliament. Therefore in this case we could have "serious violation of law" and consequently competitiveness of these two responsibilities.

Despite the specification of the above cases is understandable that they should not be taken as exhaustive cases but as the possibility that they occur more often in practice. It is understood that the practice can bring other cases of violation of the constitutional provisions by local authorities, which should be verified case by case.

\section{Serious Breach of the Law}

Regarding the second cause, provided by Article 115 of the Constitution, discharging and dissolving of the directly elected institutions from the Council of Ministers for "serious violations of law" we find more cases in the constitutional jurisprudence. It is therefore defined as follows:

Given the content of Article 115, paragraph 1 of the Constitution of the Republic of Albania, under which the Council of Ministers may dismiss the body of the local government elected directly, the Constitutional Court considers that the exact meaning of the concept of fair and serious violations of the law used in this constitutional provision must be assessed in its entirety by several factors related to the importance of the violated law, the consequences of the violation, duration of these effects, as well as the subjective position that holds the specific person to violation (Constitutional Court, 2000).

From the above constitutional statement, results that the entirety of the factors that constitute "a serious violation of the law" are:

a) The importance of the violated law;

b) The consequence of this breach;

c) The duration of these effects;

d) The attitude of the subject to the violation committed

As Constitutional Court has accepted, the above mentioned factors should cumulatively prove, therefore these elements must exist simultaneously. In relation to the first element - the importance of the violated law - the doctrine accepts that these laws deal mainly with the organization and functioning of these organs, but it can happen that they may have connection with other various laws, defining other responsibilities for these bodies, always within the nature of their functions (Abdiu, 2001).

Another moment accepted by the constitutional jurisprudence is related to the type of responsibility. A violation that is attributable to the local institution may have elements of administrative / disciplinary responsibility, as well as elements of criminal responsibility. The latter as a rule competes with administrative responsibility and administrative responsibility not always competes with that offense (Dobjani, Toska, Puto, E.Dobjani, 2013). In these cases, according to the Constitutional Court:

The Constitutional Court considers that, as a general rule, the criminal liability competes with administrative or disciplinary responsibility. In addition, despite the criminal proceedings, the administrative body of the Council of Ministers, can simultaneously initiate an administrative proceeding for offenses for which administrative liability is ascertained (Constitutional Court, 2008).

From the above it results that the Council of Ministers, whether on a local authority has initiated a criminal proceedings and regardless of the manner of its conclusion, there is no impediment to proceed administratively the body. However in these cases, the Council of Ministers would argue the respective offenses and administrative responsibility of the local authority to proceed, as well as will be argued below, the mere fact of starting a criminal proceeding, does not make a serious violation of the law.

By the jurisprudence of the Constitutional Court are considered as serious violations of the law, the movement of the municipality governative center by the mayor in excess of his powers (Constitutional Court, 2000). Executive body failure to report to the representative body. Also, are considered serious violations of the law the call of the representative body in breaches of the rules and with people who are not its member (Constitutional Court, 2000). Actions inconsistent 
with its functions are considered non submission of the acts of the executive body to be controlled in the prefecture or prevention and not sending the acts of the representative body (Constitutional Court, 2000). Other serious violations accepted by the jurisprudence, are tender procedures if involved the executive body itself or his family (Constitutional Court, 2006). In addition to violating the provisions of the legislation that regulates the activity of the local bodies, even the violation of other laws but which give competences to the local authorities can be regarded as a serious breach of the law, such as the distribution agricultural land several times to several owners affecting private rights and public entities 9Constitutional Court, 2008).

Serious law violations are also considered the false statements and / or concealing the asset declarations by the executive body of the local unit and that is administratively verified by the competent authority (Constitutional Court, 2011).

It is important to note the fact that when it comes to administrative responsibility, such violations shall not be of technical character and should be charged to the local authority itself. In cases where such violations are committed by the local administrative structures within the unit, as the finance office, the relevant committees (procurement, billing, inventorying) or other employees, as well as in cases where the local authority has taken all possible measures for the normal operation of the local administration, then based in the constitutional jurisprudence, in these cases we are not dealing with serious violations of the law (Constitutional Court, 2005.

Besides the serious violation of the law, as a constitutional concept, the organic law of the local government seem to imply other cases for dismissal of local bodies. Specifically in relation to the dismissal of mayors of the municipalities Icommune the law provides that:

The Mayor of the municipality/commune may be dismissed by the Council of Ministers when:

a) commits serious violations of the Constitution or laws;

b) is convicted of committing a criminal offense by a final decision of the court;

c) is proposed for dismissal from the relevant municipal council for absence from duty for a period of 3 months, uninterrupted (Law "On the organizations and function of the Constitutional Court of the Republic of Albania", 2000).

From this provision results that the case determined by the letter "a" is the same case defined by Article 115 of the Constitution. Two other cases seem to be different cases by the constitutional provision. However, if we analyze these two predictions carefully, we will see that we are dealing with various forms of serious violations of the law, which are clearly specified by the lawmakers. The sentence given by the court for committing a criminal offense, which has become final, cannot be considered as a serious violation of the law, as in this case are violated the criminal law norms, which are important for protecting the social relationships. This argument finds support in the constitutional case-law (Constitutional Court, 2013). Maintaining this interpretation line made by the Constitutional Court, is considered as a serious breach of the law, the punishment of a mayor with the court's final decision, for the offense of duty abuse. In this case, given that the offense for which the complaining entity was convicted, directly involved the exercising of his functions as mayor, then the Constitutional Court has described as completely right the decision of the Council of Ministers (Constitutional Court, 2009).

Final judicial punishment for committing a criminal offense, also serves as cause for dismissal regardless of whether the offense for which the entity is convicted does not have direct connection with the functional tasks of the entity. Thus the constitutional jurisprudence has recognized as valid cause for dismissal, even when a person is declared guilty for the crime of refusing to declare, disclose, concealment or false statement of assets of persons elected and public officials as provided by Article 257 / a, first paragraph, of the Criminal Code (Constitutional Court, 2013). In the instant case, the refusal to declare the property regardless of not being directly related to the functional activity violates local body image and therefore also constitutes a serious violation of the law.

Referring to the constitutional jurisprudence is not considered a serious violation of the law the fact that towards such an entity has begun an investigation. If the attributable violations do not have elements of administrative violations, a person cannot be dismissed from the duty of the local unit chairman, only due to the commencement of criminal prosecution, because in this case we would have a violation of the principle of presumption of innocence (Constitutional Court, 2009).

However, if a serious violation of the law that the Council of Ministers has attributed to the local proceeded authority is based solely on grounds which contain only elements of criminal acts and this fact has also started a criminal prosecution, in this case, the Constitutional Court has decided the suspension of constitutional adjudication, pending upon the completion of the criminal investigation and possibly the relevant trial (Constitutional Court, 2013).

Referred to the constitutional jurisprudence, is not cause for suspension of constitutional adjudication, the case when the person who complained was found guilty and submitted a request for reviewing the final decision at the 
Supreme Court. In these cases, this request could be taken into consideration only if the Supreme Court would have decided to suspend the implementation of the final criminal decision (Constitutional Court, 2009).

A controversial issue that has sparked debate is the fact whether the requirements of other countries for extradition do constitute or not serious violations of the law. The constitutional jurisprudence has given a positive respond, if the extradition request is accepted by the Albanian courts. And in a decision of the Constitutional Court we found this reasoning:

The Court finds that the Albanian state, except the cases of the extradition request rejection, as defined in Article 491 of the Criminal Procedure Code, recognizes the criminal acts of foreign authorities, in this case those of the Italian justice, issued to Albanian citizens, the legality, validity and formal validity of which is controlled by the Albanian justice authorities during the judicial administrative procedure of extradition.

In this case, the Court finds that the Albanian justice authorities, when verifying the legal requirements identified above, there have been no legal obstacle, invalidity or legal groundless that will lead to the rejection of the request for extradition. Rather, the District Court and Court of Appeal of Shkodra, in their decisions have assessed the reasonable doubts based on evidence which warranted admission of the applicant's request for extradition (Constitutional Court, 2013).

From the above analysis results that according to the Constitutional Court, accepting the extradition acts of a state from the Albanian courts, which have create a reasonable doubt based on the evidence that the person committed the offense for which extradition is requested, constitute a serious violation of law.

In fact this conclusion is even more questionable in itself. So, in the concrete case it raises the question, which is the law that is seriously violated. Extradition request for a specific person, requesting him to be tried in another country does not mean automatically that this person have violated the law (even if a law of a foreign country). The trial in another country may not necessarily end with the conviction guilty of the person extradited. Such an approach of reasoning where the only cause of dismissal is the demand for extradition violates the principle of presumption of innocence.

Regarding other cause predicted by the organic law of the local government, the proposal of the municipal/commune council for the mayor dismissal because of his failure to go to work for more than 3 months, I have the opinion that this case is classified as a specific case of serious violations of the law by the executive body. According to the organic law of the local government and some other laws that meet regulatory framework of local government, the executive body of the municipalities and communes has significant powers. His absence for more than three months without justifiable reasons, results in blocking of the activity and non normal functioning of the local unit. For this reason, such an approach can be regarded as a serious breach of the law, related even with the consequences that may come. It is understandable that the Council of Ministers is not obliged by the proposal of the representative body. He is obliged to initiate an administrative procedure to assess the coming impact of failing to exercise the functions and at the end of the process based on his discretion can eventually decide.

While regarding the cases that are related to the dissolution of the representative bodies of the municipalities/communes for serious violations of law, case law does not exist in this case, because to date there has been no decision of the Council of Ministers for these organs. As a deduction we may say that the same principles analyzed above in the case of dismissal of the executive branch of local government units are valid by analogy to the representative bodies. An important point worth emphasizing is the fact that the decision of dissolution a representative body affects the whole council in its entirety. In this way is considered complete the mandate of those consultants who may have had the opposite approach with the majority decision makers of the representative body. Consequently, in this case are penalized even those persons who have been aware of the serious violations of the law and for this reason have voted against.

The Law on Organization and Functioning of Local Governments sets other cases that serve more specifically as a cause for dismissal of the council of the municipality/commune. Thus, under Article 38 of this Law that:

1. The Municipal or Communal Council can be dissolved by the Council of Ministers before the termination of the regular mandate in the following cases:

a) It does not meet for an uninterrupted period of three months;

b) It is not able to adopt the budget three months after the deadline determined in Article 19 of this Law;

c) It commits serious violations of the Constitution or other laws.

2. The Communal or Municipal Council is also dissolved after a reorganization for the change of boundaries, according to Article 70 of this Law.

3. In case of dissolution of the Council, new council elections are held in the respective commune or municipality, in accordance with the Election Code of the Republic of Albania 
Excluding the case of the letter "c", which is similar to the constitutional formulation analyzed above, the cases provided by the letters "a" and "b" of paragraph 1 of this provision although may seem as new causes, essentially are included within the concept of "serious violation of the law." Thus malfunctioning of the representative body for more than 3 months is a serious violation of the law, because in this case we do not have any exercise of the duties and responsibilities that the law has charged to the body. Based on the same reasoning, serves also the other cause defined by law, like the non approval of the local budget, which is the most important act for meeting the needs of the communities, is a serious violation of the law, as a result of non exercising the functional tasks.

The other case determined by paragraph 2 of Article 38 of the organic law of the local government has to do with another situation known and regulated by the Constitution, the local government reorganization. In this case, the representatives body shall be dissolved because also the local unit in which it did part no longer exists, is extinguished ipso lege and has nothing to do with the dissolution of the local bodies provided for by Article 115 of the Constitution.

A controversial issue raised by the doctrine, is the question whether can serve as a cause for dismissal or dissolution, the offenses committed against the decisions of the Council of Ministers or its instructions and then can serve as a reason for this, actions that fall in conflict with specific orders or ministers' instructions (Abdiu, 2001)?

This question arises because the word 'laws' in the Constitution is used to mean different thing, in some cases meaning only the formal sense of laws and in some other cases the right in general, including the bylaws. This fact is acknowledged even by the constitutional jurisprudence (Constitutional Court, 2006). Joining the opinion submitted by the doctrine, which considers that in this case the term "law" in the Constitution, is used in its broad sense then we can say that serious violations of Council decisions and instructions of Ministers can serve as cause for dissolving or dismissing the local units. The contrary position that a serious violation of the guidelines and decisions of the Council of Ministers cannot serve as a reason to undertake such measures, would bring great damage to the state and governing activity and would create problems that would impede the fulfilment of the main tasks of the general state policy and would create several problems in government policies (Abdiu, 2001).

\section{Decision-Making of the Constitutional Court}

Decision making of the Constitutional Court at the conclusion of judicial inquiry in cases of reviewing these disagreements seems simple. If during the constitutional trial results in violations of the fair hearing right or violations attributed to the local authority does not exist or cannot be considered serious, then the Constitutional Court decides the acceptance of the request, resulting in cancellation of the decision of the Council of Ministers.

Otherwise, if the request is considered as unfounded, the Constitutional Court decides its collapse. In the case of application failure referred to Article 115 item 3, of the Constitution, the President of the Republic sets a date for holding of elections in the respective executive unit body or the representative. Despite this, the announcement of early elections day for the executive body will not happen, if we are in the last six months of the mandate. In these cases, the representative body itself elect the local government mayor who performs the functions for the remaining period (Law "On the organizations and function of the Constitutional Court of the Republic of Albania", 2000).

\section{Conclusions}

The main purpose of this analysis is to give an idea of the mechanism that has been adapted by the Constitution of the Republic of Albania in order to control the local units activity. Until now in different cases this system has resulted functional and effective, thereby ensuring the uniform application of legislation by local units.

However, the Constitutional Court has clearly pointed out that, despite the uniqueness of this kind of trial, the Council of Ministers is obliged to respect the elements of due process. The local institutions which does not agree, has the right to appeal to the Constitutional Court, in order to review the legitimacy of such decision adopted by the Council of Ministers.

This guarantee is foreseen in order to protect the rights of local units which still remain elected bodies and therefore represent the people.

So, the Constitution has tried to maintain a balance between the unity of the state and local government autonomy.

\section{References}

Xhezair Zaganjori; Aurela Anastasi, Eralda Çani, (2011) "Shteti i së drejtës në Kushtetutën e Republikës së Shqipërisë", Tirana, Publisher "Adelprint". 
Fehmi Abdiu, (2001), "Kushtetuta dhe Gjykata Kushtetuese e Republikës së Shqipërisë", Tirana, Publisher "Redona".

Ermir Dobjani, Elsa Toska, Erlir Puto, Erajd, Dobjani (2013) "E drejta administrative - Kontrolli mbi administratën publike", Tirana, Publisher "Emal".

\section{Legal Text}

Constitution of the Republic of Albania 1998

Law no.8577, date 10.02.2001 "On the organizations and function of the Constitutional Court of the Republic of Albania".

Code of Administrative Procedure 1999

Decisions of the Albanian Constitutional Court, available from

http://www.gjk.gov.al/web/Vendime_perfundimtare_100_1.php

Decision no.24, date 04.05.2000

Decision no.25, date 04.05 .2000

Decision no.37, date 23.06.2000

Decision no.50, date 31.07 .2000

Decision no.37, date 29.12.2005

Decision no.39, date 29.12.2005

Decision no.20, date 11.07.2006

Decision no.30, date 28.12.2006

Decision no.22, date 07.10.2008

Decision no.2, date 29.01.2009

Decision no.14, date 08.06.2009.

Decision no.15, date 08.06.2009

Decision no.15, date 03.05.2011

Decision no.29, date 27.06 .2013

Decision no.32, date 10.07.2013

Decision no.37, date 25.07.2013 